http://dx.doi.org/10.12775/szhf.2017.031

ÁDÁm SMRCZ

EÖtvös LorÁnd University / Institute of Philosophy,

Hungarian Academy of Sciences, Budapest, Hungary

E-MAIL:SMRCZADAM@GMAIL.COM

\title{
The Spectre of Stoicism - the Role of Justus Lipsius in the Hobbes-Bramhall Debate
}

\section{Introduction}

John Bramhall is often portrayed in a dual way: he is either regarded as an influential ecclesiastical politician (mainly famous for the role he played in the Laudian consolidation of the Church of Ireland), ${ }^{1}$ or as a harsh opponent of Thomas Hobbes. From the later perspective, Bramhall is mostly regarded as a minor figure in the history of philosophy, ${ }^{2}$ which can also be seen from a recent comprehensive interpretation of his philosophical duel with Hobbes, claiming that their debate could mostly gain significance due to its direct

${ }^{1} \mathrm{~J}$. McCafferty, The Reconstruction of the Church of Ireland - Bishop Bramhall and the Laudian Reforms, Cambridge: Cambridge University Press, 2007, pp. 21-59.

${ }^{2}$ T. Pink, "Suarez, Hobbes and the scholastic tradition in action theory", in: The Will and Human Action From antiquity to the present day, T. Pink, M.W.F. Stone (eds.), London: Routledge 2004, pp. 127-154. 
implications with contemporary political life, not due to its philosophical content ${ }^{3}$.

Bramhall was regarded - even by his contemproraries - as a follower of Arminianism, a school famous for (1) its leanings towards Rome - in ecclesiastical affairs -, and (2) endorsing a quasi-Pelagian attitude towards human salvation rejecting the Calvinist doctrine of double predestination, which, on the other hand, (3) also implied a libertarian position in metaphysics. ${ }^{4}$

According to Jackson's argument, the Hobbes-Bramhall debate must therefore be interpreted within the framework of Arminianism and anti-Arminianism, but the investigation also has to be restricted to that of ecclesiastical politics, since - as he says - the question of state supremacy over ecclesiastical power was at its heart (if metaphysical determinism is true, then the role of ecclesiastical services will be meaningless, and consequently the clergy should not be endowed with power to act in worldly affairs).

In my view, Jackson was right in emphasizing the role of Arminianism in the debate, but his intention to regard the whole matter as that of ecclesiastical politics is not justified enough. ${ }^{5}$ My approach to the question will, hence, be mostly different: while keeping in mind the importance of Arminianism, this paper will focus on Bramhall's libertarian position. As his readers frequently point out, Bramhall was a follower of the scholastic tradition, and more particularly, that of Francisco Suárez. ${ }^{6}$ Suárez held an incompatibilist position regarding free agency, saying that only those agents acted freely, which still had the capacity to act otherwise even after all the necessary prerequisites of their action have been given [omnibus requisitis positis]. ${ }^{7}$ A necessary agent on the contrary - lacked the capacity to refrain from its action if all these

${ }^{3}$ N. D. Jackson, Hobbes, Bramhall and the Politics of Liberty and Necessity, Cambridge: Cambridge University Press 2007, pp. 20-40.

${ }^{4}$ R. Colie, Light and Enlightenment, Cambridge: Cambridge University Press 1957, pp. 36-49.

${ }^{5}$ Jackson's argument is weakened by the fact that the Arminians - similarly to Hobbes - held an Erastinian position regarding the supremacy of the state over the church which would render Hobbes' anti-Arminian efforts almost meaningless.

${ }^{6}$ T. Pink, "Suarez, Hobbes and the scholastic tradition in action theory”, in: The Will and Human Action From antiquity to the present day, T. Pink, M.W.F. Stone (eds.), London: Routledge 2004, pp. 127-154.

7 "Every effect is, hence, constituted by certain accidents of the agents and the patients, in the presence of which accidents an effect will arise, but is any of them is missing, it will not arise. The accident, belonging either to the agent or to the patient, without which effect can not arise, is called as the sine qua non cause, as something that is hypothetically necessary 
prerequisites were present. ${ }^{8}$ In the latter case, even the omnipotence of God was insufficient to hinder the occurrence of the action: God's only option in order to prevent the action of a necessary agent was to withdraw one or more of the necessary prerequisites. ${ }^{9}$

These are the outlines of Suárez's and Bramhall's hypothetical necessitarianism. The very title of Bramhall's first treatise against Hobbes, the Vindication of True Liberty from Antecedent and Extrinsical Necessity seems to suggest that there are - at least - two problematic issues (viz. antecedent and extrinsical necessitation), and the number of controversial points seems to increase even further later on. As Bramhall says:

"And if [appetitive sense] should produce a kind of necessity, yet it is but moral, not natural; hypothetical, not absolute; coexistent, not antecedent; from ourselves, not extrinsecal". ${ }^{10}$

But - as I intend to show - (1.) these (moral, hypothetical, coexistent, and intrinsical types of necessitation) can all be reduced to one single question: to that of hypothetical necessitation. On the other hand, the contrary views (viz. those of natural, absolute, antecedent, and extinsical necessitation) can also be reduced to one single aspect: to that of absolute necessitation.

The later claims are also summarized by Bramhall under one single umbrella term: that of Stoicism. One should not forget that a major part of their debate with Hobbes was constituted by a rhetorical struggle, within which Bramhall insisted on labelling Hobbes a Stoic, while Hobbes repeatedly rejected this accusation. By contrast, the latter was constantly trying to make

[necessarium per hypothesin], or something that is required in order to produce an effect". T. Hobbes, Elementorum Philosophiae Sectio Prima De Corpore, London 1655, pp. 74-75.

${ }^{8}$ Suárez enumerated eight such prerequisites: (1) the cause has to be endowed with enough power to operate; (2) the cause has to have a patient proper to endure an effect; (3) if there is an intermediary between the agent and the patient, it should not hinder the process of causation; (4) There should not stand a cause of equal or even higher power opposed to the cause, since the former would hinder the operation of the latter; (5) The object has to be in a condition appropriate to endure an agent's operation; (6) in case the effect presupposes the operation of another cause (like that of an object visible in the case of seeing), this prerequisite also has to be given; (7) the cause should not be a free one; and finally (8) the cause has to be endowed with divine concourse. See: Francisco Suárez, Disputationes Metaphysicae, in: Opera Omnia, 25, Paris: Apud Ludovicum Vives 1861, pp. 688-689.

${ }^{9}$ Disputationes Metaphysicae, p. 692.

${ }^{10}$ J. Bramhall, "A Vindication of True Liberty from Antecedent and Extrinsecal Necessity", in: The Works of Archibishop Bramhall, Part the Third containing the Discourses against Mr. Hobbes, Oxford: John Henry Parker 1844, pp. 91-92. 
the impression of merely pouring new wine into old wineskins by adhering to the terminology of the schoolmen, and also calling himself a hypothetical necessitarian.

Besides reducing the number of the seemingly manifold questions of the debate, this paper has two more purposes: it intends to show, that (2) Bramhall succeced in unmasking Hobbes' absolute necessitarianism, and also, (3) he was right when he interpreted Hobbes in a particular framework: that of Lipsianism. Justus Lipsius is famous for being the founder of the so-called Neostoic movement, who first outlined his theses on determinism and free agency in his best-selling work, De Constantia (1584), but gradually modified them in his later works, the Politica sive Civilis Doctrina (1587), the Monita et Exemplaria Politica (1605), but even more importantly in the Physiologia Stoicorum (1604) - albeit according to some views, there is no substantial difference between the major theses included in these works. ${ }^{11}$

\section{Only hypothetical and absolute necessity matters}

In the following passage, I will show that the number of problematic questions mentioned by Bramhall can be reduced to one fundamental one: whether the claim of hypothetical or absolute necessity is true? As we have seen it, the author contrasted (1) moral necessity with natural; (2) hypothetical with absolute; (3) coexistent with antecedent; (4) intrinsical with extrinsical. After investigating the proper meaning of each of these pairs, we will turn our attention to which one of these matters.

\subsection{Intrinsical vs. Extrinsical Necessity}

Bramhall begins the Vindication with an epistemological argument: he quotes Hobbes, who said that he had "resolved to answer" Bramhall's objections formulated against him. ${ }^{12}$ For him, resolution presupposes two neccessary conditions: (1) deliberation on the subject and (2) dominion over our actions. If any of these fails to materialize, the act of resolution will not be

${ }^{11}$ J. Sellars, "Stoic Fate in Justus Lipsius's De Constantia and Physiologia Stoicorum", Journal of the History of Philosophy, 52, 2014, pp. 653-674.

${ }^{12}$ Vindication, p. 24. 
free, since it would be necessitated or spontaneous at best. ${ }^{13}$ Hence, any such thing as a "predeterminated resolution" would be a contradictio in adjecto, and holding a necessitarian position while claiming to have "resolved to" something would amount to a performative contradiction.

The resolution can be regarded as a free act if and only if the agent had previously "obtained the cause" of his action (meaning that the cause of his action was not external to him). For Bramhall, the phenomenal content of the act (viz. one's internal perception of himself being able to act otherwise) proves that the resolution was carried out freely, but from a metaphysical point of view, such arguments can be easily regarded as invalid. And this is exactly Hobbes' strategy since he aims to discredit any epistemological argument based on one's introspection:

The question therefore is not, whether a man be a free agent, that is to say, whether he can write or forbear, speak or be silent, according to his will; but whether the will to write, and the will to forbear, come upon him according to his will, or according to any thing else in his own power. I acknowledge this liberty, that I can do if I will; but to say I can will if I will, I take it to be an absurd speech. ${ }^{14}$

As it can be seen, the question of "obtaining the cause" does not concern the underlying question of where the agent obtained the cause from. If the claim of physical necessitarianism is true, then our primary volitions are determined by it. But, as we have seen, Hobbes rejected the existence of higher order ones. He only took liberty in the negative sense (as the absence of constraints), and hence, volitions were free - according to him - when no obstacle was there to hinder them, regardless from whether they had been determined to one or not.

Therefore, the question of "whether I have obtained the cause" was not the right one to ask, since both parties in fact agree on it, and the claim of physical determinisim should have been in focus.

\footnotetext{
${ }^{13}$ Bramhall made an important distinction between necessity, spontaneity and liberty. While he employed the traditional definition of necessity as the "antecedent determination to one", he regarded spontaneity as the "conformitiy of the appetite [...] to the object". Spontaneity was, hence, liberty without deliberation, since the later was defined by him as "the elective power of the rational will". Vindication, p. 28.

${ }^{14}$ Vindication, p. 27.
} 


\subsection{Moral vs. Natural Necessity}

And this is the point where their paths diverge, since Bramhall - following Suárez - regards the concourse of God as one of the necessary prerequisites of an action (see: footnote 8 ), while Hobbes only speaks of the interplay between secondary causes without that of the first one. In order to further highlight God's role, Bramhall even reintroduced the Jesuit distinction between moral and natural necessity. As he says:

No man is extrinsecally, antecedently, and irresistibly necessitated by temptation to steal. The devil may solicit us, but he cannot necessitate us. ${ }^{15}$

The same is formulated in more detail in Suárez's 22th Disputation. Here, he claimed that God could sometimes use free causes, but not by physical necessitation:

If God wills to use [a certain] secondary cause in order to produce a certain effect, he has a peculiar way to do that (which is rather moral, than physical). Sometimes by agitating and moving secondary causes (as in the case of good deeds), sometimes by letting and permitting them [to act] (as in the case of bad ones). This is due to the infinite wisdom of God, by which he foreknows, how a free cause will operate in a certain time and among certain circumstances. ${ }^{16}$

Since a free cause, by definition, is something that can act or refrain from acting according to its own will, the above mentioned divine sollicitation or permission still has to be regarded as a new prerequisite of an action, which, however, still does not necessitate the latter.

Hobbes, on the other hand, denies to have heard of such a distinction at all $^{17}$ - a claim very unlikely to be true. Still, according to him, actions emerged from such complete causes (or causae integrae), where both the agent and the patient were secondary causes, and whose combinaton would inevitably cause a certain effect. ${ }^{18}$ Hence, Bramhall's reliance on the above mentioned distinction was of no use from the debate's point of view and could only reveal some of his opponent's theological implications.

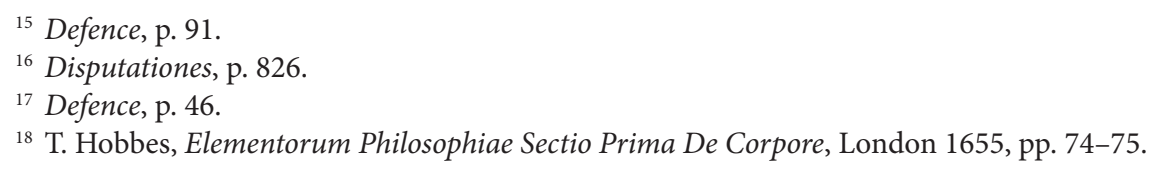




\subsection{Coexistent vs. Antecedent Necessity}

On the contrary, the questions concerning coexistent and antecedent necessity play a major role in the debate. According to Bramhall, no-one has ever, or would question the claim of necessity in the composite sense (in sensu composito), but still, the same claim in the divided sense (in sensu diviso) is untenable. Or, to put it differently: the claim that "Socrates sits and runs” is false, since it is necessary that Socrates either sits or runs. However, the claims that "Socrates sits" and "Socrates runs" (taken separately) do not imply logical contradiction, since neither of them is necessary.

Bramhall, hence, approves of the concept of coexistent necessity, claiming that whatever is in a certain way, it cannot be otherwise at the same time:

When we question whether all occurrences be necessary, we do not question whether they be necessary when they are, nor whether they be neces sary in sensu composito after we have resolved and finally determined what to do, but whether they were necessary before they were determined by ourselves, by or in the pre cedent causes before ourselves, or in the exterior causes without ourselves. ${ }^{19}$

Coexistent necessity would not, hence, amount to necessitation at all. Still, necessitation in the divided sense is regarded by him as an unacceptable doctrine. Two subspecies can be distinguished from necessity in the divided sense: antecedent and absolute necessity. The two differ only regarding their points of view, since antecedent neccessity implies a temporal succession of a cause and an effect, while absolute necessitarian claims hold that an effect can be necessitated simultaneously by its cause.

To the first one, Bramhall attributes a twofold origin: (1) divine foreknowledge, or (2) necessity resulting from the concourse of secondary causes.

Bramhall solves the first problem (1) by denying the causal relationship between divine foreknowledge and creation:

But that the foreknowledge of God should be a cause of anything, cannot be truly said; seeing foreknowledge is knowledge, and knowledge depends on the existence of the things known, and not they on it. ${ }^{20}$

\footnotetext{
${ }^{19}$ Vindication, p. 25.

${ }^{20}$ Ibid., pp. 58-59.
} 
All this draws heavily on Bramhall's voluntarism, according to which the will of God can - at least in theory - be moved independently from his intellect, that is to say, God may not necessarily conform to the dicates of his (fore)knowledge. Although God's causal interference in worldly affairs is not denied at all, still, it is not related to his knowledge of the created things.

Concerning the other, (2) Bramhall comes up with the question of divine concourse as a necessary prerequisite of an action: according to him, the causa integra also presupposes a divine interaction in each and every worldly event besides the appropriate disposition of secondary agents and patients.

\subsection{Absolute vs. Hypothetical Necessity}

All this leads us to the questions of absolute and hypothetical necessity. On a rhetorical level, (1) Hobbes expressedly claimed himself to be a hypothetical necessitarian, accepting only the possibility of the necessitas consequentiae, not that of the necessitas consequentis: according to him a consequence could be necessary only if all requirements were readily given - although, he later adds, that such are always given.

If I shall live, I shall eat. Indeed it is a necessary proposition, that is to say, it is necessary that that proposition should be true, whensoever uttered: but tis not the necessity of the thing. ${ }^{21}$

For him, the hypothetical neccessitarian position is a contradiction in terms, but he, nevertheless, prefers to call his own position hypothetical. Writing approximately at the same time, Hobbes spoke thus in the De Corpore:

Every cause of every effect is therefore based on the accidents of the patients. If all these accidents are given, effect will follow, and if any of them is missing, effect will not follow. We call that accidental the cause sine qua non, which belongs either to the agent or the patient, and without which the effect can not come to pass. We [also call this] hypothetically necessary [necessarium per hypothesin], or [something that is] required to produce an effect. The cause simply, or the total cause [causa integra] is composed of the aggregate of all accidentals - either if we speak of agents or patients of any number -, and supposing that they are all given [omnibus suppositis], it is inconcievable, that an

\footnotetext{
${ }^{21}$ Ibid., p. 122.
} 
effect would not follow. But if any of them is not given [desit], it is inconcievable that an effect would follow.22

Hobbes does not speak of the predetermination of the prerequisites here, since that would concern the operation of the primary cause - a question, which is almost entirely missing from the De Corpore - but, as we shall see later, he regarded the primary cause as something necessarily determinating all the secondary causes. Still, this seemingly hypothetical position also entails what Bramhall calls antecedent necessity right in the title of his criticism. If the necessary prerequisites are given, then a complete cause is given, and action must follow with the agent having no option to act otherwise.

(2) As can be seen, the Hobbesian account of hypothetical necessity lies on the contingency of the prerequisites. But the contingency, or not being caused by a certain cause, is taken by Hobbes in a perspectivist way: in one of his examples, he says that the claim "it is rainy today" is a contingent one only because I myself, who is caught in this rainy weather, did not cause the rain. Talking from any other perspective, for example from that of the previous state of the universe, the same phenomenon could be regarded as necessary.

And this is exacly the case with the prerequisites, or necessary accidentals - as he calls them. If the formaton of a complete cause depends on the contingent concourse of accidentals, this contingency will also be a matter of perspective. This is why Bramhall insightfully questions Hobbes' views on the role of the primary cause, the reply for which is that it does necessitate secondary causes in case it concurs with them.

Hobbes claims not a single but a multiple chain of causes exist, all depending on the primary one. Without any concourse - to keep Hobbes' words - all these causes would remain inert. A concourse is, hence, a necessary for them to act, and what Bramhall inquires is wheter the primary cause can determinate the whole chain to one, or not. Hobbes needs to reply the following:

Nor doth the concourse of all causes make one simple chain or concatenation, but an innumerable number of chains joined together, not in all parts, but in the first link, God Almighty; and consequently the whole cause of an event does not always depend upon one single chain, but on many together [...]. Now it is manifest, that the First Cause is a necessary cause of all the effects

${ }^{22}$ De Corpore, p. 74. 
that are next and immediate to it, and therefore, by his own reason, all effects are necessary. ${ }^{23}$

One may understand the point of the rhetorical struggle taking place between Hobbes and Bramhall here: Hobbes calls the connection of causes in his system „concourses”, while Bramhall intentionally calls it concatenation:

as I called it "a concatenation of causes" and as he calls it, "a concourse of necessary causes". ${ }^{24}$

Hobbes is certainly not a concurrentist - or, at leat, not in the sense how Bramhall takes it - since all he can conceive of is the concourse of secondary causes, while the primary merely plays an indirect role for him.

\section{Hobbes and the Question of Absolute Necessity}

The hypothetical and absolute necessitarians both claimed that no agent was endowed with a capacity to act otherwise if all these requierements were once given. The main difference between the two necessitarian positions was that the absolute necessitarians held that prerequisites would be given necessarily (and, hence, a consequence would also necessarily follow), while the hypothetical necessitarians denied the latter claim. According to the absolute necessitarians, even God would not be able to prevent the occurence of events, while the hypothetical necessitarians claimed the opposite, but - to use Francisco Suárez's example - only by taking away one or more of necessary prerequisites of the event.

Bramhall accused Hobbes of holding the absolute necessitarian views, a standpoint he often identified with Stoicism. Although the bishop did not define it clearly what he meant by the term, still there is one particular position he identified Hobbes with at a certain point of the debate: that of Justus Lipsius. In his De Constantia (1584), Lipsius outlined his theory of causation by drawing up a distinction between the concepts of fatum violentum (later to be referred to as stoic fate) and verum fatum (or christian fate).

\footnotetext{
${ }^{23}$ Vindication, p. 118.

${ }^{24}$ Vindication, p. 60.
} 
[...] the patrons of necessity, being driven out of the plain field with reason, have certain retreats of distinctions which they fly unto for refuge. First, they distinguish between Stoical necessity and Christian necessity, between which they make a threefold difference. ${ }^{25}$

The former was meant to serve as an umrella term encompassing the ancient stoics views on determinism, while the later was intended to refer to the Lipsian correction of these earlier claims. In Bramhall's view, the Stoic position was untenable even after the Lipsian corrections, and he used Lipsius as a typical example for the errors of necessitarians (suggesting, of course, that Hobbes is following the same path as well). The latter entirely rejected to be interpreted in such a framework:

[Bishop Bramhall] says a man may perhaps answer that the necessity of things $[\ldots]$ is not a Stoical necessity but a Christian necessity, etc. But this distinction I have not used nor indeed ever heard before, nor could I think any man could make Stoical and Christian two kinds of necessity, though they may be two kinds of doctrine. Nor have I drawn my answer to his Lordship's arguments from the authority of any sect, but from the nature of the things themselves. ${ }^{26}$

However, Bramhall rejected Hobbes' apology, took his claim only as an attempt for a rhetorical manipulation:

But yet he likes not the names of "Stoical" and "Christian" destiny - sais Bramhall - (do not blame him), though he would not willingly be accounted a Stoic. To admit the thing, and quarrel about the name, is to make ourselves ridiculous. ${ }^{27}$

\subsection{Hobbes, the Lipsian?}

As Vere Chapell noted, it was highly unlikely that Hobbes had not heard about this distinction before, since he had even referred to Lipsius elsewhere - although not to the De Constantia. ${ }^{28}$

\footnotetext{
${ }^{25}$ Ibid., p. 115.

${ }^{26}$ Ibid., p. 118.

${ }^{27}$ Defence, p. 119.

${ }^{28}$ Hobbes and Bramhall on Liberty and Necessity, V. Chapell (ed.), Cambridge: Cambridge University Press 1999, p. 29.
} 
The original Lipsian taxonomy consists of four accounts on fate, two of which are immediately rejected by the author without explicitely demonstrating their implausibility. ${ }^{29}$ In turn, he offers a third type, called (F.3) fatum violentum. He credits the Stoics with having invented this theory, without calling any attention to the diversity of Stoic opinions on the question; hence, the concept of fatum violentum can be regarded as Lipsius' own invention (although one obviously looking back on ancient forerunners). The early modern usage of the term violens most generally refered to the extrinsical necessitation of an event, ${ }^{30}$ and Lipsius also gave it the name, because the fatum violentum is supposed to neccessitate events extrinsically, or, as he put it: "it is connected to all things and actions, which is not broken by any kind of power". ${ }^{31}$ Although Lipsius explicitely sympathises with this account - created by himself -, he even emphasizes the hardships involved in it: according to him it is untenable that (O.1) the stoics subordinnated God to fate; (O.2) that they claim the existence of an eternal chain of physical causes (caussarum naturalium); (O.3) that they denied the possibility of any continglent (possibile) event to be carried out; (O.4) and also denied the possibility of free will in humans.

These are exactly the concerns Bramhall will also raise against the Lipsian concept of fatum vilentum (and these will also constitute later the basis of Ralph Cudworth's criticism on the stoic theory of agency as well). ${ }^{32}$ Bramhall correctly suspects that Hobbes does - or at least: would - endorse this Lipsian account.

\footnotetext{
${ }^{29}$ Regarding the first two ones: (F1) is called fatum mathematicum, which was originally outlined by the Pythagoreans and Hermetic thinkers. According to this theory, physical events are determined by the physical operations of heavenly bodies, which, in turn, are governed by the metaphysical laws of divine providence. The second one (F2) was called by Lipsius fatum naturale, a theory he attributes to the peripatetics. According to it, events are necessitated in a somewhat hypothetical way, namely, that they will be carried out if no physical obstacle hinders their occurance. Hence, the chain of causes can be broken theoretically, but if no physical obstacle is present, the event will necessarily occur. See: J. Lipsius, De Constantia libri duo, Antwerp, 1584, pp. 55-57; J. Sellars, „Stoic Fate in Justus Lipsius's De Constantia and Physiologia Stoicorum", Journal of the History of Philosophy, 52, 2014, 653-674; Á. Smrcz, The Problem of "Stoic Fate" - Or whether Herbert of Cherbury was a Lipsian, Kultura i Edukacja 2016/2, pp. 177-194.

${ }^{30}$ See: Disputationes Metaphysicae, p. 636.

${ }^{31}$ De Constantia, p. 57.

${ }^{32}$ R. Cudworth, A Treatise Concerning Eternal and Immutable Morality with a Treatise of Freewill, S. Hutton (ed.), Cambridge: Cambridge University Press, 1996, pp. 228-231.
} 
Replying to the objections - raised againt himself - Lipsius gave a corrected account of fate called verum fatum. Here, Lipsius introduces three major novelties compared to the previous account: (1) he makes a sharp distinction between providence and fate (the former being a rational order to which the latter is subordinated). This relationship mirrors that distintion between the divine intellect and will, which is described here in a rather voluntaristic manner. (2) Lipsius also comes up with the concept of secondary causes, the dispositions of which can influence the way divine power is distributed in the created world, and hence, (3) can result in contingent events. ${ }^{33}$ Still, as Bramhall and some other interpretators have pointed out eversince, this new Lipsian concept also fails to meet libertarian requirements, since it does not guarantee the ability to act otherwise under any circumstances. This can be seen from the conclusion of the Lipsian account as well:

[...] fate is like a master of ceremonies, which holds the strings during the dance in which the whole wold takes part: but in a way, that our parts should be able to will and not will [certain things]. But we do not have more power [vis efficiendi] than this, since we were given only the opportunity, to be free to be reluctant and to stuggle against God [reluctari et obniti]; but power [vis] was not given by which we could do that. ${ }^{34}$

What the author does here is a radical departure from the traditional concepts of agency, since by drawing a distinction between will (voluntas) and power ( vis), he intended to challenge the very premises of scholastic accounts on the matter. By declining the possibility of mental causation, Lipsius takes a harder determinist standpoint than most of his ancient forerunners, and rather comes close to Spinosism.

When claiming that a causal relationship can occur between (1) differrent mental states or between (2) God and the created world, he obviously intended to save the concept of divine fate (or providence); however, his theory entailed considerable hardships from the aspect of human agency. Supposing that no causal relationship exists between $P$ (a mental state), and $P^{\prime}$ (its re-

\footnotetext{
33 "Is there something like fate? [Yes, there is], namely the primary cause, which, in turn, does not control [tollit] secondary causes, only as much as it acts through them [...]. Among the secondary causes there is your will as well, and you should not think, that it is controlled and possessed by God. [...]. God, who is the creator of everything, uses [utitur] them all without destroying them". De Constantia, p. 68.

${ }^{34}$ De Constantia, p. 20.
} 
alization in the physical wolrd), one should also accept the possibility of the two processes working separately. For instance, (1) one may decide to lift his hand and see that his hand immediately rises - as it is the case most of the time. Still, accodring to the Lipsian account, this would be only accidental since no causal relationship can be established between the two processes. However, such a case could also occur when (2) one decides to lift his hand and his had does not rise. This may also be in harmony with our ordinary experiences since cases of numbness or those of paralysis can be imagined. The real problem is that the Lipsian account enables the occurence of such cases as well when (3) one decides not to raise his hand and it nevertheless raises. This is the case which is absolutely counter-intuitive and might have seemingly worried Lipsius as well.

This might be the reason why Lipsius seems to be - discreetly - distancing himself from this position as early as in his following work, the Politica seu Civilis Doctrina (1587). Here, he provided an account which might explain why such events can not - or at least do not - occur when one's body acts independently of one's mental command. Here, he envisages a twofold series of events: (1) the physical one, occuring independently of ones will; (2) the mental one, occuring in harmony with the command of God. Lipsius keeps his rejection of mental causation here as well but makes divine intervention necessary for the operation of creatures. As he puts it:

no deliberation or help is enough to avoid or change [the course of events]. The fatal disposition of divine providence [diuinae prouidentiae fatalis dispositio] can not be subverted or reformed either by prudent deliberation or wise remedies. ${ }^{35}$

Since the book is intended to teach rulers how to act prudently (and, hence, is mostly and rightfully read as a mirror for princes), one might wonder how prudence can be considered at all upon such deterministic grounds. According to the Lipsian answer, one must will what God has decreed, and if the intentional object of his will corresponds to the very event carried out, his will be regarded as prudent (although no causal relationship is established between the two). This is further highlighted by the claim, according to which God's omnipotence can interfere with mental events as well, or, as Lipsius put it:

${ }^{35}$ Politica, pp. 26-27. 
that higher intellect takes away the reason [mentem] of men: he corrupts the deliberations [consilia] of those, whose fortune he wants to change. ${ }^{36}$

As can be seen, Lipsius advises rulers to conform themselves to the will of God (viz. to whatever is inevitably about to come to pass) not because the latter could be changed by any means, but because practical hardships can be avoided only in this way. The Hobbesian definition of freedom corresponds to all this: Hobbes defined will as the last element in a chain of deliberation ${ }^{37}$ which - following the concept of negative liberty - can be regarded as free if nothing hinders its operation. Liberty and (absolute) necessity may be compatible with each other - just like in Lipsius' case.

\section{Conclusions}

The aim of this paper was twofold; (1) I inteded to confine Bramhall's manifold objections to one single claim. According to my thesis, Bishop's main concern was to refute the claim of absolute necessity, and the rest of his objections were only subsidiary ones besides this. (2) Bramhall managed to unmask Hobbes' alleged "hypothetical necessitarianism" and (3) also identified his absolute necessitarian claims as something inherent in Lipsianism as well. In my view, the author was right when drawing a parallel between Lipsius and Hobbes, since their compatibilist standpoint, claiming the compatibility between physical necessity, and the freedom of judgement are similar (especially to the account provided by Lipsius in the Politica, the work which is philologically proved to have been known by Hobbes).

\footnotetext{
${ }^{36}$ Politica, pp. 26-27.

${ }^{37}$ Hobbes and Bramhall on Liberty and Necessity, V. Chapell (ed.), Cambridge: Cambridge University Press 1999, p. XV.
} 


\section{Bibliography}

Bramhall, John, "A Vindication of True Liberty from Antecedent and Extrinsecal Necessity", in: The Works of Archibishop Bramhall,Part the Third containing the Discourses against Mr. Hobbes, Oxford: John Henry Parker 1844.

Colie, Rosalie, Light and Enlightenment, Cambridge, Cambridge University Press 1957.

Cudworth, Ralph, $A$ Treatise Concerning Eternal and Immutable Morality with a Treatise of Freewill, S. Hutton (ed.), Cambridge: Cambridge University Press, 1996.

Hobbes, Thomas, Elementorum Philosophiae Sectio Prima De Corpore, London 1655.

Hobbes, Thomas, "Short Tract on First Principles", in: The Elements of Law Natural and Politic, F. Tönnies (ed.), London: Simpkin \& Marshall, 1889.

Jackson, Nicolas D., Hobbes, Bramhall and the Politics of Liberty and Necessity, Cambridge: Cambridge University Press 2007.

Lipsius, Julius, De Constantia libri duo, Antwerp, 1584.

Lipsius, Julius, Iusti Lipsi Epistolarum selectarum chilias, Lyon, 1616.

Lipsius, Julius, Physiologia Stoicorum libri tres, Antwerp, 1610.

McCafferty, John, The Reconstruction of the Church of Ireland - Bishop Bramhall and the Laudian Reforms, Cambridge: Cambridge University Press 2007, pp. 21-59.

Pink, Thomas, Suarez, Hobbes and the scholastic tradition in action theory, in: The Will and Human Action From antiquity to the present day, T. Pink, M.W.F. Stone (eds.), London: Routledge 2004.

Sellar, John, "Stoic Fate in Justus Lipsius's De Constantia and Physiologia Stoicorum", Journal of the History of Philosophy, 52, 2014.

Smrcz, Ádám, "The Problem of "Stoic Fate" - Or whether Herbert of Cherbury was a Lipsian", Kultura i Edukacja 2016/2.

\section{Summary}

The aim of this paper is to highlight two interrelated aspects of the HobbesBramhall debate (focusing mainly on Bramhall's merits): (1) the numerous issues raised in the dispute can be reduced to one fundamental question (to that between hypothetical and absolute necessity), and although Hobbes intended to seem like a hypothetical necessitarian, Bramhall was successful in unmasking his opponent. (2) Hobbes' absolute necessitarian standpoint is also correctly identified by Bramhall 
as a (partial) recapitulation of Lipsian Stoicism. Hence, by drawing up the outlines of Lipsius' determinism and its effects on Hobbes' philosophy, the paper intends to call for the reconsideration of Lipsius' importance in the history of philosophy.

Keywords: Thomas Hobbes, John Bramhall, Julius Lipsius, stoicism, necessity, determinism 